\title{
Vesa Haapala
}

\section{Runon puhujasta, puhetilanteesta ja puheenomaisuudesta}

Arvioin Avaimessa 1/2008 turkulaisten tutkijoiden laatiman lyriikan oppikirjan Lentävä hevonen. Välineitä runoanalyysiin (Vastapaino, 2007). Kritiikkini innoittamina kirjan toimittajat Siru Kainulainen ja Karoliina Lummaa avasivat Avaimessa 3/2008 omista näkökulmistaan keskustelun runon puhujasta ja puheenomaisuudesta nostamalla esiin puhujan käsitteen osittaisen ongelmallisuuden ekokriittisen runouden ja rytmillisen runouden tutkimuksessa. Nämä avaukset ovat kiinnostavia mutta niin laajoja, etten voi tässä yhteydessä tarkemmin kommentoida niitä. Siksi tyydyn täsmentämään asiaani ja korjaamaan keskeisen käsitteellisen väärinkäsityksen.

Selvyyden vuoksi siteeraan kritiikkini katkelman, joka antoi aiheen vuoropuheluun:

Vaikka Lummaan (motiivia ja teemaa käsittelevä) artikkeli on oivaltava, sen sijoittaminen kirjan alkuun on sikäli hankalaa, että kirjoittaja joutuu toistuvasti viittaamaan neljänteen pääjaksoon "Puhuja". Vasta siellä nimittäin esitellään lyriikka-analyysille keskeisiä puhujaa ja puhetilannetta jäsentäviä työvälineitä. Sama hankaluus toistuu Lummaan osuutta seuraavassa pääjaksossa "Rytmi”. Lyriikkaa voi toki lähestyä eri tulokulmista, mutta mietin "Kohti tulkintaa" -jakson luettuani pitkään teoksen esitysjärjestyksen luontevuutta. Itse ainakin alan analyysin hahmottelemalla puhetilannetta ja puhujan identiteettiä; nuo kysymykset tulevat ennen teemaa. Myös perinteisesti runon rakenneosia eriteltäessä on lähdetty liikkeelle puhetilanteesta. Näin edeten saadaan esiin lajinäkökulma ja lyriikkaa muusta kirjallisesta kommunikaatiosta erotteleva ominaislaatu. Lentävän hevosen ratkaisu jättää puhujaosuus viimeiseksi on varmasti motivoitu, mutta hieman vierastin järjestystä, jossa tulkintaa alustavat kehykset edeltävät runoudelle lajityypillisten piirteiden esittelyä.

Täsmennän vielä, että arvioin edellä Lentävä hevonen -teoksen esitysjärjestyksen sekä runouden rakenteiden ja konventioiden esittelyn luontevuutta oppikirjayhteydessä. Kritisoin siis lievästi sitä, että puhujaa koskeva jakso on jätetty teoksessa viimeiseksi. Osittain kritiikkini taustalla oli valaiseva lukukokemus, jonka tarjosi norjalaisten tutkijoiden oppikirja Lyrikens liv (2004). Siinä lähdetään liikkeelle kysymyksestä ”Mitä lyriikka on?” ja esitellään monipuolisesti sekä runouden lajityypillistä piirteistöä että runouteen kohdistuvia teoreettisia odotuksia. Näissä odotuksissa puhujalla ja puheen tilanteella on keskeinen asema. Toki lyriikan kohdalla myös rytmi (säe, säkeistö, erilaiset rytmin hahmottamisen tasot) olisi mahdollinen aloituspiste, kuten Auli Viikarin esimerkit osoittavat, ${ }^{1}$ mutta se vaatisi laajassa yleisesityksessä melkoista innovatiivisuutta kirjoittajalta. 
Miksi sitten pidän puhujaa ja puhetilannetta olennaisena lähtökohtana, kun esitellään lyriikan keskeisiä analyysivälineitä ja tulkinnan lähtökohtia perustason oppikirjassa? Ensiksikin vetoan tutkimuksen traditioon. Uuskritiikistä lähtien lyyrisiä runoja on luettu ikään kuin tietyn puhujan jossakin tilanteessa esittäminä tai ajattelemina kompleksisina lausumina tai niiden verbalisaatioina. Toinen, sisällöllisempi huomioni liittyy siihen, että vaikka runous tuo kirjallisuuden lajeista kenties selkeimmin esiin sanan materiaaliset ja rytmiset eli ei-semanttiset kvaliteetit, toimii se suhteessa lukijaan ensisijaisesti kommunikatiivisessa ja artikuloivassa ulottuvuudessa. Näin on silloinkin, kun runous tietoisesti problematisoi viestintätilanteen ehtoja ja häiritsee merkityksen tai puhujan idententiteetin hahmottumista. ${ }^{2}$ Näiden seikkojen vuoksi runon tilanteen tai puhetilanteen jäsentäminen on hyödyllistä ja välttämätöntä. Puhetilannetta tarkastellessaan lukija paikantaa suhteensa siihen diskurssiin, jota hänelle tarjotaan. Konventionaalisesti käsitteellistämme tätä tilannetta runon puhujuuden analyysissa.

Palaan myöhemmin vielä siihen seikkaan, että runon puhujan / puheen ja puheenomaisuuden modaliteetin välille ei voida ongelmitta vetää yhtäläisyysmerkkejä. Puhuja on samankaltainen metaforisesti muodostettu tutkimuksellinen postulaatti kuin "ääni”, ja niiden molempien juuret ovat lyriikan äänteellisessä ja esitystilannetta koskevassa menneisyydessä. Näitä käsitteitä käytetään siitä huolimatta, että runoudella on nykyään vähintään yhtä vahvat kytkökset tekstuaalisiin ja visuaalisiin keinoihin kuin puhuttuun tai esimerkiksi musiikin kanssa esitettyyn sanaan. Tästä syystä puhujan käsitettä ei voida ajatella kaikissa tapauksissa täysin kirjaimellisesti.

Oppikirjan etenemisjärjestystä koskevan kritiikkini selkeyttämiseksi teen pienen rinnastuksen tilanteeseen, jossa tutkijoiden tehtävänä olisi laatia oppikirja proosan analyysista ja tulkinnasta. Lajien välillä on luonnollisesti eroja ja teoreettisen esityksen voi rakentaa monella tapaa, mutta mielestäni analogia on valaiseva. Oletan, että proosan oppikirjaa laadittaessa olisi luontevaa määritellä ensin kerronnan minimiehtoja ja proosan lajipiirteitä, samoin kuin analysoida kertojan käsitettä. Mukaan voisi nostaa myös ainakin osin henkilöhahmoja koskevia tulkintamalleja. ${ }^{3}$ Nämä kaikki rinnastuvat statukseltaan lyriikan puhujan ja puhetilanteen käsitteistöön. Tällainen puhetilannetta ja teoksen puhetilanteiden hierarkkisia tasoja kokonaisuutta jäsentävä käsitteellinen malli hallitsee myös Lentävän hevosen puhujaosuutta, ei suinkaan Kainulaisen ja Lummaan esiin nostama "puheenomaisuus". Nähdäkseni kysymykset kertomisesta, kertojasta ja henkilöhahmosta ovat kaikessa problemaattisuudessaan proosan lajipiirteiden kannalta nykyäänkin ensisijaisempia kuin esimerkiksi teeman ja motiivin käsitteet, jotka voidaan rinnastaa lyriikan kuvallisuuden alueeseen (trooppeihin, figuureihin, skeemoihin, topoksiin, toki myös lyriikan motiivi- ja teemarakenteisiin). Tämän analogian nojalla olisi siis hieman hankalaa, joskaan ei mahdotonta, ajatella kerronnasta tehtyä oppikirjaa, jossa esimerkiksi proosan ajallisuuden ja motiivirakenteiden jäsen- 
tymiseen liittyvät kysymykset esiteltäisiin ennen kertomisen ja kerronnan määrittelyä; tässä tapauksessa ajallisuuden kysymykset vastaisivat lyriikan rytmin ongelmakenttää.

Kritiikissäni ei ollut missään nimessä kyse siitä, että puhetilanteen ja sitä myötä lyriikan keskeisten lajipiirteiden hahmottamisen olisi jokaisessa käytännön analyysissa tultava esiin ensin ja oltava aina ensisijaista suhteessa lyriikan muiden rakenteiden tarkasteluun. Opetuksessa voidaan painottaa mitä hyvänsä näkökulmaa aineiston ominaislaadun, käsiteltävien asioiden ja pedagogisten tarpeiden mukaan. Puutuin vain siihen, millainen järjestys olisi ollut luonteva oppikirjaksi tarkoitetussa yleisesityksessä niiden osaesitysten puitteissa, joista Lentävä hevonen rakentuu.

En ota tässä tarkemmin kantaa niihin jatkokysymyksiin, joita Kainulainen ja Lummaa puheenvuoroissaan esittävät. Tahdon kuitenkin sanoa, että pidin sekä ekokriittiseen runoudentutkimukseen että runouden rytmiin vievistä avauksista. Molemmat veivät keskustelua tärkeisiin suuntiin ja osoittivat hienosti sen, miten laji muuttuessaan luo uusia vaatimuksia teorialle. Avauksien tarkempi kytkeminen puhujuuteen painottuvaan lyriikantutkimukseen toisi varmasti esiin tuoreita näkökohtia ja tarkennuksia moneen suuntaan.

Yhden olennaisen väärinkäsityksen tahdon kuitenkin korjata, sillä se on Kainulaisen ja Lummaan puheenvuorojen ehkä määrävin ponnin. En ole missään viitannut runon puhujan käsitteellä siihen runon puheenomaisuuteen, jonka etenkin Kainulainen nostaa esiin. Puheenomaisuuden modaliteetti, josta on keskusteltu muun muassa vapaarytmisen runon piirteenä, ei kuulu siihen puhujuuteen kytkeytyvään lajikäsitteistöön, josta kritiikissäni ja edellä kirjoitin.

Kirjallisuudentutkimuksen oppikirjoihin kohdistuu aina kohtuuttomia odotuksia. Jokaista lukijaa on mahdoton miellyttää. Tahdon vielä nostaa esille kirja-arvioni keskeisen sanoman: Lentävä hevonen täyttää mainiosti ja monipuolisesti tehtävänsä. Toivonkin kirjalle runsasta lukijakuntaa. Kiitän teoksen toimittajia innostavista puheenvuoroista ja uskon, että pääsemme keskustelemaan niistä jatkossa tarkemmin, ehkäpä myös Avaimen sivuilla!

\section{Viitteet}

${ }^{1}$ Auli Viikarin esitys "Lyriikan runousoppia” Runousopin perusteissa (1990) lähtee liikkeelle runokielestä ja poeettisesta funktiosta eli lyriikalle lajityypillisistä piirteistä ja siirtyy sitten äänteellisen tason toistorakenteiden eli rytmin analyysiin. Muutoin Viikarin eteneminen vastaa esitysjärjestykseltään pitkälti Lentävän hevosen ratkaisua. Viikari luo väitöskirjassaan Ä̈̈neen kirjoitettu (1987) ja artikkelissaan "Att beskriva rytmen i fri och bunden vers: ett förslag till en analysmodell" (1989) runon rytmisyyden analyysimallin, jonka avulla voidaan kuvata käytännössä runon jokaista toiston tasoa: fonologista, grammaattista, semanttista, pragmaattista ja typografista. Tällainen malli voisi hyvin toimia rytmistä alkavan teoriaesityksen pohjana.

${ }^{2}$ On selvää, että runon puheelle antavat sille ominaisen leiman lyyrisen rekisterin muutkin 
elementit, joiden kanssa se on saumattomassa vuorovaikutuksessa. Tarkoitan kuvallisuutta ja säkeen rytmistä kontrollia sekä toiston erilaisia muotoja.

${ }^{3}$ Laji- ja muotopiirteitä sekä kertojuuden ehtoja painottaviin ratkaisuihin päätyy esimerkiksi nykyisin opetuksessa käytetty Suzanne Keenin teos Narrative Form (2003). Shlomith Rimmon-Kenan rakentaa taas klassikkoteoksensa Narrative Fiction: Contemporary Poetics (1983, Kertomuksen poetiikka) tarinan, tekstin ja kerronnan kategorioiden ympärille. Lähtökohtana ovat lajin erityispiirteet, ja teoretisointi liikkuu tällöin pitkälti kerronnan, kertojan ja henkilöhahmon käsitteiden ympärillä. Tosin jälkinarratologisessa keskustelussa kertojan käsite on haastettu voimakkaasti, ks. esim. Richard Walshin haastattelu tässä numerossa. Tosin silloinkaan ei irrottauduta henkilöhahmon ja kerronnan käsitteistä.

\section{Lähteet:}

JANSS, CHRISTIAN, ARNE MELBERG \& CHRISTIAN REFSUM 2004: Lyrikens liv. Introduktion till att läsa dikt. Övers. Enel Melberg. Göteborg: Daidalos.

KAINULAINEN, SIRU, KAISU KESONEN \& KAROLIINA LUMMAA 2007 (toim.): Lentävä hevonen. Välineitä runoanalyysiin (2007). Tampere: Vastapaino.

KEen, suzanne 2003: Narrative form. Basingstoke: Palgrave.

Rimmon-KenAn, Shlomith I983: Narrative Fiction: Contemporary Poetics. London: Methuen.

VIIKARI, AULI I987: Ä̈̈neen kirjoitettu. Vapautuvien mittojen varhaisvaiheet suomenkielisessä lyriikassa. Helsinki: SKS.

VIIKARI, AULI I989: Att beskriva rytmen i fri och bunden vers: ett förslag till en analysmodell. Från fornyrdislag till fri vers. Studier framlagda vid Första nordiska metrikkonferensen, Göteborg 24-26 september 1987. Skrifter utgivna av Centrum för Metriska Studier 1. Red. Sven Bäckman, Anita Kruckenberg \& Eva Lilja. Göteborg: CMS, 7-19.

VIIKARI, AUlI I990: Lyriikan runousoppia. Mervi Kantokorpi, Pirjo Lyytikäinen \& Auli Viikari, Runousopin perusteet. Helsinki: Helsingin yliopisto, Lahden tutkimus- ja koulutuskeskus, 39-102. 